\title{
SOCIAL IDENTITY, CHURCH AFFILIATION, AND LANGUAGE CHANGE IN KWARA'AE (SOLOMON ISLANDS)
}

\author{
Karen Ann Watson-Gegeo and David Welchman Gegeo
}

\section{INTRODUCTION}

The Solomon Islands were al ready a complex multilingual region (70-90 language varieties $\left.{ }^{1}\right)$ before contact with Europeans led to the introduction of English and the development of Solomon Islands Pijin (SIP) on plantations (Bennett 1979, Siegel 1986, Watson-Gegeo 1987). Today, although English is the official language of government and schools, SIP (now a creole) is the primary language of urban Honiara, and the national lingua franca spoken by perhaps $65 \%$ of the population (Jourdan 1986, 1989). In most rural areas, villagers continue to speak an indigenous language. But English and SIP are the languages of political power and social influence, and as the solomon Islands is increasingly drawn into the world socioeconomic and political system, the importance and respect accorded local languages in the past is eroding.

While socioeconomic factors have often been the focus of language variation studies, church affiliation and its consequences have been less studied. The historical role of the christian missions, together with colonialism, in shaping language use and attitudes in the Pacific islands and elsewhere has long been recognized, of course (e.g., Boutilier, Hughes, \& Tiffany, eds., 1978, Hilliard 1966, 1978, Whiteman 1983). Today as in the past, church affiliation in the solomons is closely associated with people's aspirations for education, economic development, and lifestyle. These concerns are important factors in why the now largely nativized christian churches continue to play a major role in the direction of language change.

This paper examines language change, social identity, and church affiliation among Kwara'ae-speaking people of Malaita. In Kwara'ae district and in Kwara'ae settlements near Honiara on Guadalcanal, intense competition for converts among several churches is having a significant impact on language choice and change. We focus on the South seas Evangelical church (SSEC) and the Church of Melanesia (CM; Anglican) as illustrative. Drawing on Giles' (1973) accommodation theory and Bell's (1984) 
audience design framework, we show that Kwara'ae SSEC and CM members operate out of different models for ranking language varieties by social prestige, and that they signal their separate identities through linguistic code, discourse patterns, and nonverbal aspects of communication. The characteristics we identify are illustrated in transcripts from four Kwara'ae speakers.

ACCOMMODATION THEORY AND AUDIENCE DESIGN

Giles' accommodation theory (e.g., Giles, Bourhis, \& Taylor 1977) addresses social categorization (e.g., by ethnicity, social class, or religion), and its relation to people's motivation to adjust speech styles, together with the resulting sociopolitical consequences. Especially relevant here are the conditions under which speakers are likely to use convergent, nonconvergent, or divergent strategies in accommodating to the speech of a higher or lower socially ranked group. In Giles' model, these choices derive from perceptions of whether social change in the rank of the subordinate group is possible and desired (viewed positively or negatively), and according to relative social power. Table 1 summarizes Giles' accommodation model with regard to perceptions of social change and speaker responses.

Table 1 -- Expected Individual and Group Linguistic Accommodation Behavior According to Perceptions of Social Change

Response

Perception of social change Dominant group Subordinate group

no possibility of social change perceived

possibility of social change perceived favorably

possibility of social change perceived unfavorably

nonconvergence convergence

'downward' convergence

divergence

divergence $\quad(\text { variable })^{2}$

(Adapted from Fasold 1984: 190, based on Giles et al. 1977) 
Although potentially a powerful explanatory model of language choice and speech style, accommodation theory has been criticized as linguistically naive (Fasold 1984). Accommodation theory appears to assume that a given speaker commands a range of competencies in linguistic varieties, and can freely choose among them. This is an empirical question which would have to be ascertained for individual speakers, as uniformity within a social group seems highly unlikely. In a multilingual situation such as the Solomon Islands, people's repertoires are strongly affected by length of schooling, work history, and residence patterns. Moreover, cross-linguistic communication -- with speakers talking in their own languages but with sufficient listening comprehension to understand the other - - is not uncommon, and reduces the need to expand one's repertoire. Furthermore, access to certain linguistic varieties or to opportunities to gain a given competence level in them is always a political issue wherever language varieties are associated with differential social prestige and political power.

Similar problems with assumptions about speakers' code and discourse range are found in Bell's (1984) "audience design" framework, which attempts to account for style shift choices made by individual speakers in specific social contexts. In Bell's model, all style shifting -- including by topic or setting -- derives from the axiom that speakers adjust (design) their speech to a perceived audience (ibid.: 180-181). Audience roles, defined in relation to how speakers respond to or initiate style shift, include: addressees, auditors (full participants who may also take turns as addressees), overhearers (who listen legitimately), eavesdroppers (who overhear by intention or chance), and referees (non-present reference group). All are defined by whether the speaker knows them to be there, ratifies them as participants, and directly addresses them. The five audience roles are summarized in Table 2: 
Table 2 -- Hierarchy of Attributes and Audience Roles in Speaker Response to and Initiation of Style Shift

\begin{tabular}{l|ccc}
\hline Audience Role & Known & Ratified & Addressed \\
\hline Addressee & + & + & + \\
Auditor & + & + & - \\
Overhearer & + & - & - \\
Eavesdropper & - & - & - \\
Referee & - & + & - \\
\hline
\end{tabular}

(adapted from Bell 1984:160)

Speakers respond primarily to addressees, assessing their personal characteristics, general speech style level, and (probably) levels for specific linguistic variables (ibid.: 167). Non-addressee audience roles may affect such qualitative aspects as choice of speech act or bilingual language switch (ibid.: 176), and sometimes are actually more salient to the speaker than the identity of the addressee. By initiating style shift, speakers can redefine the relationship between themselves and the addressee (ibid.: 185), and in Giles' terms, may converge or diverge with the addressee or others. High salience referees may affect speaker behavior more than those who are actually present.

Although Giles and Bell's models provide useful frameworks for examining language choice and change at the societal and individual level, their limitations must be recognized. Speakers are often ambivalent about the social value of the linguistic codes they know, the extent of their own competence in them, and the relative merit of choosing a particular code in complex social circumstances. Individuals vary as to whether their prestige rankings of linguistic codes and their audience design decisions remain relatively stable and reenacted across changing contexts, or reflect genuine choices within a repertoire as shaped by immediate contextual influences. Most importantly, choices of discourse style and non-verbal behavioral patterns are at least as important as choice of linguistic code for claiming identity (Burke 1969) with a given social group. 
We turn now to a brief historical account of language use in solomon Islands churches and its effect on societal language change.

\section{LANGUAGE AND CHURCH IN HISTORICAL PERSPECTIVE}

From the turn of the century until the 1960s, schooling in the solomons was mostly in the hands of the christian missions (McGavin \& Gannicott 1989; Searle 1970). The languages of instruction in mission schools varied greatly by sect and across time (see Whiteman 1983). At one point or another, various local languages, English, Pijin, and even Mota (a language of Vanuatu) have been the language of school instruction and/or church liturgy.

The Melanesian Mission (MM, later CM; established 1848) at first used local vernaculars in rural areas and Mota in its Norfolk Island boarding school where Melanesian missionaries and catechists were trained. The MM valued indigenous languages and some aspects of traditional culture. But the language issue was hotly debated from the late 1800s to the 1920s. The decision to use Mota to follow Melanesians' "own thought patterns and social values" (Hilliard 1978: 204) was intended to produce convergence in religious belief while assuming nonconvergence in language and culture (since missionization by outsiders was to be a temporary process). Some clergy, however, argued for English as "the path to secular knowledge and advanced education overseas" (ibid.). They feared that without English, Europeans and Asians would out-compete islanders in government and business. Here, convergence by the subordinate group was to lead to the possibility of social change. However, this argument was also connected to the British Protectorate government's insistence that mission schools train islanders as clerks for civil service. Ultimately, convergence to English was intended to support rather than supplant the colonial social system.

Melanesian Mission boarding schools (first opened in the Solomons in the late 1890s) switched to English in 1925, due to demand from Solomon Islanders, the need to attract potential students away from plantation work (with the promise of employment in government service as clerks), and difficulty in finding British teachers willing to learn a Melanesian language (Searle 1970: 11). Village schools gradually shifted to English over the next several decades. From the 1940 s to 1970s, the MM boarding schools were considered the best in the Solomons for training an islander elite in English. on 
Malaita, church liturgy, hymns and prayers were translated into well-formed high rhetoric (formal register) Kwara'ae.

The South Seas Evangelical Mission (SSEM, later SSEC; established in Queensland in 1904) accompanied pidgin-speaking plantation workers when they returned home from Australia shortly after the turn of the century, to take new jobs on the plantations just being set up in the solomons. The SSEM used the evolving SIP in schools and services, greatly contributing to its spread throughout the archipelago. The SSEM aim seems to have been a comprehensive religious and cultural convergence to Anglo-European beliefs. This aim has received continued support by the popularity of English in the SSEC.

Nevertheless, SSEM/SSEC missionary linguists such as Norman C. Deck and others in West Kwara'ae in the past 30 years have been active in translating the New Testament and church literacy materials into local languages. These translations have been rather unsuccessful because they are difficult to comprehend, and because of the growing local desire to learn English and Pijin.

over the past hundred years, differences in language variety or speaking style from one denomination to another in the Solomons have been used -- sometimes deliberately and sometimes inadvertently -- to attract converts, to separate them from non-converts, and to emphasize their distinctiveness from members of other denominations. Today some $95 \%$ of the population is Christian, and conversion means moving from one christian sect to another. Yet competition for converts has increased, possibly related to the 1980s worldwide upsurge of fundamentalism and evangelism, and on Malaita, to socioeconomic decline.

We turn to a very brief account of MM/CM and SSEM/SSEC in West Kwara'ae, where we have conducted research since 1978 . (For brevity, members of the two churches will be referred to hereafter as Anglicans and Evangelicals. ${ }^{4}$ )

\section{ANGLICANS AND EVANGELICALS IN WEST KWARA'AE}

Missionization in the early decades of the 20 th century accompanied a major shift in population from mountains to coastal plain, initially for access to Western goods through trade, and later because of pressure from missionaries. To minimize competition in their evangelizing efforts, the SSEM and MM partitioned West Kwara'ae based on where their original 
headquarters had been set up and who had "opened" a given village. 5 But religious rivalry was intense where adjacent villages were claimed by different missions, or a kin group was split between them.

Anglicans view Evangelicals as belonging to another Christian faith, but until the late 1970 s Evangelicals viewed Anglicans as unsaved, only a step away from "paganism" (i.e., the ancestral religion). The SSEC attitude reflected both a general fundamentalist position towards other churches, and a specific rejection of the CM's continuation of some practices from traditional Kwara'ae culture. Today, the CM is "accepted" as a christian church by the SSEC. According to this new position, Anglicans are "saved," but they do not belong to the "true church," that is, the SSEC. Evangelicals are less likely to honor kin obligations, such as contributions to the cost of marriages, when the kin group is split between sects. 6

Supported by videotapes of Australian and American televangelists, personal appearances by foreign evangelists, and the arrival of fundamentalist missionary groups under the guise of recovery efforts after Cyclone Namu in 1986, SSEC prosetylism increased in West Kwara'ae during the 1980s. Revival meetings are now held even in remote Anglican villages, accompanied by the electronic music of young Kwara'ae Gospel rock musicians whose portable sound systems were purchased with overseas support. 7 Revival meetings are exciting, and appeal to the identification of the young with the outside world and social change. Theologically, the meetings offer an ecstatic, emotional vision to rural villagers whose traditional culture emphasizes emotional control, and whose frustration with current economic circumstances is acute. The evangelizing message emphasizes not only paradise after death, but a better Iife on earth with regard to economic opportunity, development, and modernization. This latter message is symbolized by the behavioral and linguistic convergence of Evangelicals with urban reference groups.

\section{ANGLICANS AND EVANGELICALS IN KWARA'AE: BELIEFS AND LANGUAGE ATTITUDES}

As English and Pijin are valued above local languages at the provincial and national levels of solomons society, it is no surprise that West Kwara'ae people like to display their knowledge of these two language varieties. Over the past 40 years, however, Evangelicals have converged towards Western culture and urban patterns in talk and behavior more than 
Anglicans. The two groups are making different decisions on what audience characteristics to respond to in accommodating their speech. We will examine these points in relation to differential prestige ranking of language varieties, and stylistic choices in linguistic code, discourse patterns, and nonverbal aspects of communication.

Prestige ranking of language variety by church affiliation

Evangelicals and Anglicans operate out of somewhat different models for ranking language varieties by social prestige. As argued above, and because of the SSEC's greater access to overseas scholarships and development funds, for many years SSEC membership has been associated with aspirations for economic advancement, schooling, and a Western lifestyle. English primarily, and Pijin secondarily are the language varieties associated with these aspirations. In contrast, Kwara'ae is associated with the ta'anga'a 'sinfulness' of the past.

Somewhat more culturally conservative, Anglicans have been in the leadership of attempts to revitalize traditional culture or kastom (in SIP) over the past decade. The CM external network has also provided many fewer opportunities for experiences abroad or local development projects. Kwara'ae Anglicans make a distinction between the value of English and Pijin as outgroup varieties, and Kwara'ae as ingroup variety. They are particularly concerned that high rhetoric, the formal register of Kwara'ae, continue to be learned and spoken because they believe it to embody the essence of Kwara'ae culture. SSEC and CM prestige rankings are represented in Table 3, which is based on our long-term ethnographic study of Kwara'ae language use, and discussions of language attitudes by members of the Kwara'ae Language and culture committee. ${ }^{8}$ 
Table 3 -- Prestige Ranking of Language Varieties by Church Affiliation

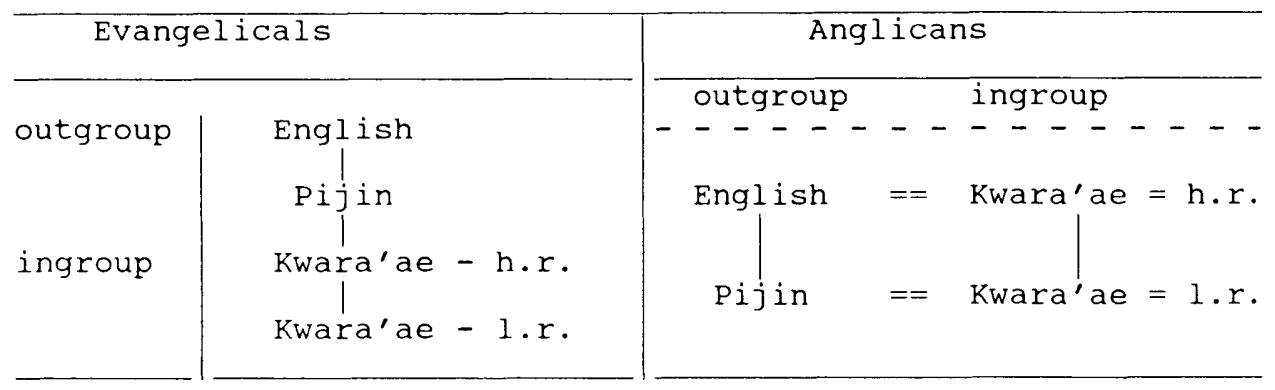

As Table 3 suggests, Evangelicals rank English, Pijin, high-rhetoric Kwara'ae and low-rhetoric Kwara'ae from high to low in a single ranking scheme, indicating a convergence to outgroup style and values as represented by educated urban Solomon islanders, the Evangelical reference group. Anglicans seem to have two tracks in their ranking system, each of which is internally ranked. High-rhetoric Kwara'ae and English are ranked equally high among Anglicans, with the choice between them dependent on audience and context. Similarly, lowrhetoric (ordinary, everyday speech) Kwara'ae and Pijin are equally ranked at a lower level vis-a-vis the high ranked varieties.

What accounts for these models and the attitudes behind them? Interestingly, both groups perceive Anglicans as speaking "proper" or "real" Kwara'ae -- a point that is repeatedly made in conversation as well as in public meetings. Evangelicals often lament their inability (even among senior generation males) to speak high rhetoric well. They say they have "forgotten" much Kwara'ae vocabulary and many subtle ways of phrasing ideas or concepts. But they take pride in the loss, equating it with the inevitable if regrettable cost of education and modernization. These attitudes are probably deepened by the increasing poverty on Malaita, and the desire for dramatic economic improvement without a clear notion of how to effect such changes.

While recognizing and valuing the higher status of English and Pijin outside Kwara'ae, Anglicans perceive Kwara'ae as associated with falafala 'tradition, culture', history, and core cultural values. Although they are sometimes ambivalent about all of these, they hope to keep a sense of identity in a time of rapid social change. Anglicans regard attempts to 
converge to outsider norms when speaking to insiders as alura'e 'pretentious' and malafaka 'pseudo-European.' Their speaking style generally converges to the immediate audience, with a preference for high-rhetoric Kwara'ae on serious and important occasions. They joke about the SSEC claim that one can forget one's native language. In village contexts, Anglican codeswitching to English beyond single vocabulary items is typically for humor, self-teasing, or satire. Yet a substantial number of Anglicans interested in rising in political or church circles do try to speak a mixture of English and Kwara'ae in village contexts, seemingly responding -- as Evangelicals do -- to an outside reference group. They are often the targets of indirect teasing and gossip.

\section{Features of linguistic code and discourse patterns}

Most Anglicans and Evangelicals who use Pijin or English words for concepts non-existent in Kwara'ae, or to signal their education and knowledge of a larger world, cannot clearly demarcate between the two languages. Thus a speaker may say, "I speak English (the local English-Pijin mix) but I don't speak grammar (school-taught English)."

Although many theological and liturgical terms (whether in Kwara'ae or English) are shared by the two sects, church vocabulary has been an important lexical domain for signalling differing church membership and beliefs. Table 4 compares a few concepts and labels in the two churches' Kwara'ae liturgy, from English, Kwara'ae, Mota, and Fijian: ${ }^{9}$

Table 4 -- Examples of English, Kwara'ae, Mota, and Fijian Terms in SSEC and CM Church Vocabulary

\begin{tabular}{|c|c|c|}
\hline & SSEC & $\mathrm{CM}$ \\
\hline $\begin{array}{l}\text { to } \\
\text { baptize }\end{array}$ & $\begin{array}{l}\text { fa'ababataese } \\
\text { caus+baptize }\end{array}$ & $\frac{\text { siuābu }}{\text { bath+holy }}$ \\
\hline baptism & $\begin{array}{l}\text { babataese'anga } \\
\text { baptize+nom }\end{array}$ & $\frac{\text { siuābu'anga }}{\text { bath+holy+nom }}$ \\
\hline $\begin{array}{l}\text { to perform } \\
\text { marriage } \\
\text { (on someone) }\end{array}$ & $\begin{array}{l}\text { fa'amariti } \\
\text { caustmarriage }\end{array}$ & $\begin{array}{l}\frac{\text { daukwailima }}{\text { hold+recipr+hand (join }} \\
\text { hands) }\end{array}$ \\
\hline
\end{tabular}


(Table 4, con't.)

\begin{tabular}{|c|c|c|}
\hline & SSEC & $C M$ \\
\hline marriage & $\begin{array}{l}\text { mariti'anga } \\
\text { marriage+nom }\end{array}$ & $\frac{\text { ara'inga }}{\text { marry+nom }}$ \\
\hline pastor/priest & $\begin{array}{l}\text { basto } \\
\text { pastor }\end{array}$ & $\frac{\text { mama }}{\text { father (Mota) }}$ \\
\hline to preach & $\begin{array}{l}\text { samon } \\
\text { sermon }\end{array}$ & $\frac{\text { funau }}{\text { preach }}$ (Fijian) \\
\hline Holy spirit & $\begin{array}{l}\text { sibirit ābu } \\
\text { spirit+holy }\end{array}$ & 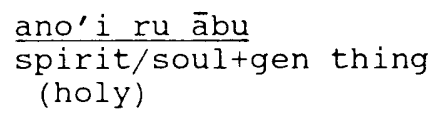 \\
\hline kingdom & $\begin{array}{l}\text { kingi'a } \\
\text { king }+ \text { nom }\end{array}$ & $\begin{array}{l}\frac{\text { talo'a }}{\text { be known+nom (of }} \\
\text { paramont chief in } \\
\text { past, hence area of } \\
\text { his jurisdiction) }\end{array}$ \\
\hline heaven & $\begin{array}{l}\text { hefen } \\
\text { heaven }\end{array}$ & $\frac{\text { langi }}{\text { heaven }}$ \\
\hline city & $\begin{array}{l}\text { taone } \\
\text { town }\end{array}$ & $\frac{\text { fanoa doe }}{\text { village big }}$ \\
\hline $\begin{array}{l}\text { room (as in } \\
\text { Upper Room) }\end{array}$ & $\begin{array}{l}\text { rumu } \\
\text { room }\end{array}$ & $\frac{\mathrm{ma}^{\prime} \mathrm{e}}{\mathrm{CL} \text { house }}=$ room \\
\hline law & $\begin{array}{l}\text { lo } \\
\text { law }\end{array}$ & $\frac{\operatorname{taki}}{\mathrm{law}}$ \\
\hline $\sin$ & $\begin{array}{l}\text { sin'anga } \\
\text { sintnom }\end{array}$ & $\frac{\text { abularora'anga }}{\text { behave+wrong+nom }}$ \\
\hline
\end{tabular}

Grammatical and phonological differences also distinguish Evangelicals from Anglicans. Deck was working in Rade (a large village south of Auki) when he translated the New Testament into Kwara'ae. For this reason, and because Rade was the SSEM church headquarters and training center, Rade dialect -- in which contracted forms abound -- became and is still the dialect of Kwara'ae spoken by Evangelicals. Translations by 
Deck and others were typically literal, in contrast to Anglican translators' attention to culturally meaningful paraphrasing. The grammatical pecularities of these literal translations are common in SSEC sermons, and have had an impact on Evangelicals' everyday speech. SSEC Kwara'ae is also characterized by simplification (e.g., loss of high-rhetoric forms) and redundancy. 10 simplification extends to the loss of subtle semantic differences between words in the Kwara'ae lexicon. All of these patterns are especially noticeable among Kwara'ae in urban Honiara, where Pijin is increasingly spoken in everyday interactions. Emulation of urban Kwara'ae may be involved in current rural speech patterns, since people regularly travel back and forth between Malaita and Guadalcanal. In Gilbert Camp and Kaibia, the two large Kwara'ae settlements near Honiara, the SSEC claims the largest church following.

Taken together, the above patterns make SSEC Kwara'ae sound like "babytalk" (children's speech) to Anglicans. In turn, the Anglican penchant for using high-rhetoric Kwara'ae forms associated with traditional practices make CM Kwara'ae sound wikit 'wicked, sinful' (SIP) and old-fashioned to Evangelicals.

With regard to phonology, in recent years nasalization of "b" consonants has been spreading through To'abaita in North Malaita. To'ambaita (as Iinguists are now spelling it) is a language closely related to Kwara'ae. To'ambaita Anglicans have not made this phonological shift to the degree of SSEC members who -- together with missionary linguists who come to Kwara'ae after working in To'ambaita -- have influenced SSEC Kwara'ae speakers. Kwara'ae evangelicals rarely nasalize "b" in everyday speech, but they do nasalize in church contexts, transforming (for example) ăbu into āmbu. SSEC speakers have also begun imitating the mispronunciations of missionary linguists working in Kwara'ae, who say (e.g.) sanggo for sango, or fangga for fanga. 11 Another example is consonant reduction, as in the SSEC reduction of $\mathrm{ngw}$ to $\underline{\mathrm{w}}$ in surnames mispronounced by Anglo-European outsiders. (Similarly, in Vanuatu, Prime Minister Walter Lini's name was originally lingi, but changed to reflect Anglo-European pronunciation of missionary orthography of a bar over the $\underline{n}$ to represent the velar nasal [personal communication, Lamont Lindstrom].) These linguistic innovations have a symbolic meaning for Evangelicals, distinguishing them from Anglicans while signalling their identity with Evangelicals elsewhere on Malaita. Imitation of missionary linguists is convergence to the opinions or behavior of an outside group with which insiders wish to be associated. 
Nonverbal aspects of communication

In mission days, Anglicans and Evangelicals were sometimes distinguished by dress or hair-do. For example, fa'isu'u 'riverlet', a hair-do featuring two parts running from front to back of the head in imitation of Anglo-European female missionaries, was worn primarily by SSEM women, and is still nicknamed sufi sikos 'seacoast (SSEM) haircut'. Short hair worn by Anglican men and women is still referred to as sufi mison 'mission (CM) haircut'. The deep blue of everyday and school uniform skirts and lava-lavas in Anglican villages is still called kala mison 'mission color'. Other than school uniforms, distinctions in dress or haircut no longer mark church membership. But kinesic, gestural, and paralinguistic differences are important.

Walking along Malaita Road with a group of West Kwara'ae relatives, watson-Gegeo has been surprised on many occasions by her companions' remarking, as people approach in the far distance, "Here come some SS people" or "Some Mison [CM] people are ahead." These judgments are based on differential styles of walking. The kinesics of Anglicans (and Catholics) is typically constrained, whereas Evangelicals may sway from side to side, take longer strides, and often swing their arms noticeably.

People say that habitual facial expressions (in public contexts) contrast between the two groups, and we have also repeatedly observed these differences. Following traditional Kwara'ae norms, Anglicans typically show serious to mildly happy facial expressions, projecting the sense of calm they associate with traditional (pre-christian) behavior and key cultural values (i.e., babato'o'anga, 'stability, maturity,' and enoeno'anga, 'delicacy, humility, gentleness'). Evangelicals typically display excited facial expressions with wide smiles, projecting the sense of intense wonder and joy they associate with being spiritually saved and in direct communication with God. Interestingly, a different pattern of distinguishing differences is found among the Kaluli of Papua New Guinea, where Christians show constrained, almost sad behavior in contrast to the dramatic, demonstrative behavior of the unconverted (personal communication, Bambi schieffelin).

Gestures and paralinguistic aspects of talk are congruent with the differences described above. Traditional Kwara'ae gestures are slow, fluid, and typically pulled back just at the moment of full extension. Eyes, chin, nose, and lips are used deictically to indicate direction. Gestures among Anglicans 
usually follow these traditional patterns. Evangelicals typically use much more open, expansive, and rapid gestures, appearing to imitate Anglo-European outsiders.

Anglicans perceive Evangelicals' default voice volume as greater than their own, with wide swings in pitch which contrast with traditional chant-like intonation contours. These characteristics are particularly obvious when listening to sermons. SSEC preachers imitate the Pentecostal preaching style of outside evangelists, and this style has influenced oratory among Evangelicals. Anglicans complain that

Evangelicals bombard one with talk, they are always singing and whistling, and that they are loud. An Anglican mother returning from taking her child to the hospital might say, "There was a very noisy SS person at the hospital," where she is assuming church affiliation from voice volume (and perhaps other characteristics). A common way to criticize "noisy" or flambuoyant behavior in an Anglican is to say, "That mison man is behaving just like a sikos man." Some of what Anglicans take to be noisy, unrestrained behavior (talking a lot, whistling and singing of hymns) is regarded by Evangelicals as "witnessing" to their faith.

Just how salient are these differences in people's momentby-moment "audience design" accommodations in speech and behavior? We will describe one of two cases we have observed in split kin networks where a member of one church changed to another, focusing on the resulting changes in demeanor and behavior.

An Anglican man we'll call Philemon, who had converted and moved to an SSEC village, later returned to his original church and village in a divorce dispute. His striking changes in speech and behavior almost cariacature the contrasts between SSEC and CM outlined above. Originally restrained and quiet in manner, Philemon became highly excitable as an SSEC member. He demonstrated his commitment to the new faith through frequent witnessing, lay preaching, and emotional displays such as crying and singing. His oratory at feasts shifted to Pentecostal style, as did his manner of gesturing, sitting, standing and walking, and paralanguage.

When he abruptly returned to the CM a few years later, Philemon's behavior just as abruptly reverted to Anglican norms. This reversion involved changes in linguistic code. During his SSEC days, Philemon's Kwara'ae contained many Rade dialect features, and was heavily sprinkled with English and Pijin words and phrases. When conversing with Watson-Gegeo, he 
always spoke the local English-Pijin mix, though she always replied in Kwara'ae. But on our return to Kwara'ae more than a year after he returned to the $C M$, Philemon conversed with Watson-Gegeo in an extremely rapid, highly complex, non-Rade Kwara'ae, often severely taxing her linguistic resources. He experienced suspicion from his Anglican relatives about the seriousness of his reconversion, and he seemed to be endeavoring to behave as Anglican as he could. Philemon's transformations suggest that people are self-conscious about linguistic and behavioral differences between sects, and that they monitor their own behavior accordingly.

We will now illustrate Anglican and Evangelical differences in the transcripts of four Kwara'ae speakers.

\section{ANGLICAN AND EVANGELICAL DIFFERENCES IN FOUR SPEAKERS}

We have selected transcripts from four speakers representing two generations, tape recorded in public oral performance contexts: two male speakers (one Anglican, one Evangelical) in their late 70 s to early $80 \mathrm{~s}$ in age, a woman (Anglican) in her mid-40s, and a man (Evangelical) in his late $30 \mathrm{~s}$.

Annanais Malo and Baddely Lita: Memories of World War II

Gegeo interviewed Annanais Malo and Baddely Lita (all names are pseudonyms) together in August 1984, retelling their World War II experiences and describing the political situation in the solomons after the war. The interview was conducted as part of an East-West center sponsored project on Pacific islanders' recollections of World War II (White, Akin, Gegeo, and Watson-Gegeo 1988; White and Lindstrom 1989). An elected paramont chief, Annanais (c. 78 years in 1984) is a former colonial clerk and retired SSEC preacher and translator who received some religious training in Australia about 25 years ago. An Anglican, Baddely (c. 82 years) is a respected gwaunga' $i$ (elder) and traditional leader who has never attended school.

With regard to linguistic code, at the beginning of the interview, Annanais asked whether to speak ala'anga tolo 'indigenous language' (i.e. Kwara'ae) or English. Gegeo (who spoke only Kwara'ae throughout) said to speak whatever was comfortable, but preferably Kwara'ae (with the expectation that their narratives would be more detailed if given in Kwara'ae). Annanais' account was a mixture of Pijin, English, and Kwara'ae as is characteristic of his speech in public contexts we have 
observed, even though he has led efforts to record Kwara'ae genealogy and other aspects of traditional culture. The following portion of Annanais' account illustrates his codeswitching and -mixing:

\section{Example 1 -- Annanais Malo 11}

Nauk sign on, duration of war/

M::' kail tuai Tulaek/

solomon Islands hetkota ne' Tulaek/

An aos ne'eir (.) 1939/

Nauk join on 'inair aia'(.) 1930

ae 1940, kail ka to' an na (.)

Australian Embarol Forces/

About two hundred/

Kiar leak mai' huan tisim 'aimil/

Tisim 'aimil 'ain hua'nga' ki $\mathrm{ma} /$

Huan fighting/

Aia' kail tua 'unair (.) 1940 (..) kail tutua an tai' asoa (.) tai' rekonaisian (.) rekonaisian plen blong Japan hemi kam/

Mid-dei ia/(.)

olraet mifala weit (.) nating hapen iet/
I signed on for the duration of the War/

Yes, we were at Tulagi/

Tulagi was the headquarters of the Solomon Islands/

That day was in 1939/

I joined on and in 1930 uh 1940, we were connected to the Australian Imperial Forces/

About two hundred (men)/

They came to teach us/

Teach us about fighting/

For fighting/

okay, we stayed thus (.) 1940 we were staying (and) one day a Japanese reconnaisance (.) reconnaisance plane came/

It was mid-day/

Alright, we waited (but) nothing happened/

Some of Annanais' code-switching is no doubt topic-related and helped him relive and describe his experiences. Noticeable in the transcription is his tendency to make a point first in one language and then repeat it in another. His report is generally lacking in descriptive detail, tending to consist of summary statements about what the British, Americans, Australians, and Japanese were planning and doing rather than what he observed or experienced himself. Annanais spoke hesitantly, his tempo rapid during Kwara'ae phrases, slow during English and Pijin phrases. His intonation contours varied, generally resembling those associated with Pijin and English more than Kwara'ae discourse. The mood or tone he established was of single-speaker performance, as in a lecture or sermon, rather than conversation (the format Gegeo uses for interviews). This apparently reflected his definition of the situation. Annanais' code selection and performance deeply affected interaction with his immediate audience. The frequent audience back-channeling characteristic of oral reporting in 
Kwara'ae is noticeably absent from the recording.

Annanais appeared to be accommodating to addressee Gegeo and auditor watson-Gegeo (but not auditor Baddely) as English speakers educated overseas. In Bell's terms, Annanais' shifts associated with the topic of War service were also an accommodation to communication with a superordinate social (reference) group: the British colonial administration, which he served before and during the war.

When Baddely began to speak, a dramatic shift in the interview occurred. Notwithstanding Annanais' example, Baddely spoke high-rhetoric Kwara'ae using English or Pijin expressions only for war-related terms lacking Kwara'ae equivalents. His account was delivered without hesitation and with the prosodic signals for audience participation typical of reporting in high rhetoric. Gegeo (and also Annanais) automatically responded appropriately with synchronous, rapidly-paced back-channeling and questions for clarification. Baddely focused on everyday life as a worker in the Labour corps, and discussed the feelings and frustrations experienced by the workers. The following example compares the two men's linguistic code and descriptive detail in explaining how signal lights functioned as warnings:

\section{Example 2 -- Annanais Malo \& Baddely Lita}

Annanais:

Kaidai ni 'earet go' all

black-out tai'hau/

$(\ldots)$ Condition green long

laeti ka (.) gas ka di'

long 'an taoen hukir/
When the air raid signal was given, all was all black-out/

Condition green and the the light (.) the lights down there would look like a city/

\section{Baddely:}

Kul rao san 'eahili ma ti hakloh ni' mai' huan koso mai' (.) ka lia ma ni sais ru lo'ko ka meo (.) kuk tua ha'sia 'eahil/

(..) Leleak nia kos ka rūa'
When we worked at the airfield and some airplanes had to land (.) we saw that it would make the thing [signal] turn red, then we'd stay away from the airfield/ After it had landed, we would 
(Example 2, con't.)

longo (.) oil kuk rao long 'akul nia ka kwao long 'an/ return to our work and it [signal] would turn white [green] again/

Baddely provided more descriptive detail than Annanais in this case as in many others during the interview, and he did so without resorting very often to English or Pijin.

Both Annanais and Baddely knew that Gegeo values highrhetoric Kwara'ae and speaks it well. Baddely accommodated to addressee Gegeo accordingly, and possibly also took the kastom (Pijin term for tradition) side of auditor Annanais' identity into consideration. In short, the two men accommodated to different aspects of the addressee's identity. In Erickson's (1975) terms, Annanais and Baddely each share features of comembership (shared experience, interests, values) with Gegeo. Annanais accommodated to Gegeo as someone -- like himself -educated overseas, exposed to a wider world, with knowledge of Anglo-European ways. To him, Gegeo is part of the, rising urban middle class, a superordinate reference group vis-a-vis rural villagers. Baddely accommodated to Gegeo as someone -- like himself -- valuing traditional Kwara'ae language and behavior, whose identity is based in the village. In these differing accommodation strategies, both men acted consistently with their church affiliation. Annanais converged towards an assumed superordinate outgroup's valued norms as imitated in his church. Baddely initiated a style shift from English/Pijin to Kwara'ae, a strategy of non-convergence to outgroup associated with his church affiliation.

\section{Miriama Sulimaoma and Meshach Tomo: oratory}

We recorded Miriama Sulimaoma's counseling speech, her first oration at a feast in her natal village, in July 1987. Now an important leader in her husband's village, Miriama (45 years old) is Anglican, and although unschooled herself, has been influential in her children's school successes. A dispute in Miriama's village had slowed a project to build a stormproof church in the wake of Cyclone Namu's devastation a year earlier. In her speech, Miriama counseled villagers to cooperate in finishing the church and in new development projects.

With regard to code, Miriama spoke only high-rhetoric 
Kwara'ae with no code-switching even for concepts for which she uses Pijin in everyday speech (e.g., sekson 'section,' is widely used for descent line, and barata 'brother' for same/cross-sex sibling, or sibling born behind/ahead of oneself/another). The following excerpts (from various parts of her oration) illustrate many features of Miriama's high rhetoric:

Example 3 -- Miriama Sulimaoma

Aia' (.) nau ku tai' saelea' long hua:na (.) sai nau... (.) hain aiburiku ... (.) kiar hiuk -- kiar dao mai' kuk tuatua hain ka dao an kal sau'laih ne' kear karaing kia oil na' an (.) Made/...

Aia' na: (.) san tua' ne' kulu (.) ne' bolhain kaul ka aul nam tai' liai:'ngwae: go' huan/

Si nau ne' nauk ngwae (1) nauk tai' 'a'an an kaul na' ngwai' ngwane ma (.) nauk oga liu saean tua' ne' kulu (.) kaul ka babto' go' (.) kaul ka aul go' tai' liai:'ngwae: san tua' ne'e:/ (.) ...

Tai' liai:'ngwae nam san raoa' kaul ki (.) huan haon kulu long/

Kul tua long 'akul di' ngwae ne' (.) kiar tae'ea long tua' kiar $\mathrm{ki} k \mathrm{ka}$ lea' long/...

Kiak sais long luam āub kiar ki ka (.) ka lea' long/

Ai' 'unair kaul ka 'unair long/
Alright, I am a little happy also for my sister-in-law... and the one behind me (younger sibling) that they came and have been staying with us, and this evening we all get together with them as they will be leaving on Monday/...

Alright, in our family, it is fitting that you all be of one mind/

Because I am the senior person of our basket of male people (our kin line's generation) and I very much want, in our family, you to all be stable (mature, settled, rational) and of one mind in the family here/...

Be of one mind for the work you do for our village, too/

Let us also live like those people who lift up their family to something good (improve conditions in the village, gain respect)/... They build their churches [taken here to represent all communal projects] and it is good/

You must do the same, too/

The only English or Pijin words used by Miriama were those without Kwara'ae equivalents, such as Made 'Monday.' She 
correctly used high-rhetoric "-i" endings and diminuitive expressions (e.g., opening her speech with "I'm not going to say anything important," and describing herself as ta'i saele'a, a 'little happy'). She developed arguments systematically, with careful placement of cohesion and coherence markers. Her even, moderate pace was punctuated with frequent pauses at the introduction of significant points so that the audience could reflect (a rhetorical feature called "important silences" in Kwara'ae). One such instance was her second- and half-second-long pauses where she claimed the authority to counsel her kin line by naming herself as senior (first-born) -- despite being a woman in a patrilineally organized society. As locally interpreted, her manner was gentle and dignified, her voice quality and prolonged vowels (in the above segments, hua:na [fuana], liai:'ngwae: [lia'ingwae], ne'e: [ne'e]) soothing.

Miriama's kinesics and gestures also reflected highrhetoric style. Indicating her desire to orate, she stood up in the shadows and joked quietly with those around her, waiting to be invited to step into the light. Once urged, she came forward hesitantly, her skirt tucked around her legs (the latter a sign of feminine modesty). Throughout, her gestures were fluid but restrained though she spoke fearlessly. With regard to affect, the expression of her feelings (subtle and encoded in diminuitives and voice quality) slowly unfolded to match the rhetorical build to a climax, and then returned to emotional detachment prior to her closing sentence, "My speech for all you my brothers has now arrived at an end." These affective characteristics are associated with the stance of falafala (tradition) speaking to the addressee through the speaker.

Miriama's addressees were members of her natal village, but she focused her message primarily on members of her immediate descent line (adult biological and classificatory siblings). Her auditors were therefore other members of the family (e.g., her aging father, her unmarried adult sister) and less closely-related descent group members living in the village. Also in attendance were two or three unrelated families who had come over uninvited from another village, when rumors of a feast reached them. In Bell's framework, they were overhearers (known but not ratified or addressed). Thus Miriama's audience structure was relatively complex.

Miriama's audience design recognized that her hearers were Anglican rural villagers, and she accommodated to their ingroup values, norms, and ideal reference group of gwaunga' $\mathrm{i}$ ki 
(elders) skilled in traditional oratory and counseling. These characteristics of the immediate audience were more salient to her than the audience characteristics (urban/foreign, outgroup values, national lingua franca, etc.) associated with the topic of her speech, development. Although Miriama is very familiar with the English-Pijin vocabulary of development (diflopmen or diflomen in West Kwara'ae) as used in rural Malaita, she did not code-switch nor are her Kwara'ae phrasings merely translations of development vocabulary. Instead, she presented development in traditional terms (e.g., "lifting up the village into something good" through communal efforts). In doing so, she displayed her mature skill in high rhetoric as a universal discourse sufficiently abstract that it is applicable to any topic or situation. By staying in high rhetoric,

Miriama signalled that she was not closing out any hearers from the main message even though she was focusing on a sub-group of close relatives. Each was to interpret her speech to fit his/her own situation, a stance taken by the lead speaker in fa'amanata'anga or traditional counseling (literally, "shaping the mind"; Watson-Gegeo and Gegeo 1990). Miriama's speech is a superb example of counseling oratory.

Meshach Tomo's oratory contrasted sharply with Miriama's. We recorded Meshach (c. 38 years old) in June 1984 at an important tribal/clan meeting in which high-ranking male leaders of two descent groups were gathered to tape-record accounts of land rights. One group had originally settled the land, then sold a large tract of it to the other. Now, both groups were threatened by another tribe/clan's claim to the entire area. The purpose of the meeting was to record the older generation witnesses as they practiced the testimony they would give the next day in Provincial court. One descent groups was split among Anglican, SSEC, and Roman Catholic churches, the other was Anglican. Of the sixteen men who gave speeches, one was Roman Catholic, four were SSEC, and the remaining 11 were Anglican.

An Evangelical, Meshach has the equivalent of an American 8 th grade education supplemented by technical training, and is employed as a senior administrative officer in Malaita Province. His speech came near the end of the meeting. Meshach attempted to speak high-rhetoric Kwara'ae. His lengthy speech was a plea to return to close, traditional kin relationships and values in order to protect land rights. Here are a few excerpts illustrating aspects of his discourse: 
Example 4 -- Meshach Tomo

Nauk to' an kal al'ang ti'ti:' go'/ ...

Kal al'ang titi' 'uri go' (.) ni sak mai' auk (.) kaidai bania' (.) ko' nau ni (.) hat 'ain al'ang an kwaima'anga saintan kulua'/...

si hital'anga 'uri ne' nauk lisia 'i nin'air kal oh aon ninia' kaul holia ma kuk tua saenai ni lia 'uri/

Dia' ne' noa' kuis dau lea' hahia ma ngeal ne' kiar huat an kulua' ki nini'a bae an bae kui daor saihtakul ne/ ... $\mathrm{Ne}^{\prime}$ nauk hital 'uri (.) sui hahan dia' noa' kias lialia lea' anai (.) an ngwai' ngeal nin kulu ma kuis (.) hai' nao' lea' ada' sulia kwaima'ang ninia' ngwai' ol kul ki tua mai' an (.) aos 'i nao' ki mai' ka leleak ka dao 'i tae'enai (.) si kwaima'ang ne'e (.) ni maman aos an (.) an bail $s$ - bail an mail maes bail ana (.) liman sa saitan ber (.) kiar tua 'ain hu (.) si kiar tua 'ain tai' akaol/

[Re: meeting itself:]

Kometi ne' sa tai ninia' ni fomim ma tai nin ka seaman nam tai ninia' ka sekretari nam tai ninia' toa u mān kometi ne'e/

Kal al'ang titi' ne'eir go'/
I have just a little speech/

Just a little speech that came to me when my grandfather was talking about love among us/

Because it is this concern I see, this little land that you all bought and we all live on it it looks thus/

If we don't take good care of it and the children that are born to us, by and by we will divide it among us/

I am worried thus, because if they do not look at it carefully this our basket of children, if we do not teach them well about this love that our old people used to live in, in the days up to now, because this love is true, the days the side - the enemy of (.) in the hand of Satan even they lived in it (.) because they lived within (the worship of) one spirit/

Who formed this committee and who is chairman or who is secretary or who stands in this committee?/

That's the little talk/

Despite his efforts, Meshach's high rhetoric was poorly formed. His sentences were often run-on or confused, with cohesion and coherence markers generally missing, and he made several mistakes in register. For instance, his opening statement used an incongruent diminuitive expression for describing an oration in high rhetoric: ti'iti'i 'little,' rather than $t a^{\prime} i$ (limiter) or ta 'some.' A comparable mistake in English would be to say, "I just want to give a tiny speech" in place of "I just want to 
older SSEC members were noticeably made uneasy. They gave short speeches, in cautious high rhetoric.

The majority of Meshach's addressees (others who gave orations), auditors (ranking kin who accompanied speakers to the meeting), overhearers (non-ranking kin who also attended), and eavesdroppers (other local villagers) were Anglican.

Meshach accommodated to Anglicans as ingroup partly because the senior SSEC members speaking before him had done so. Moreover, he wished to signal his desire to be identified with

traditional culture, especially when his speech was a plea for the split kin group to reunite in the interests of protecting the land. It is particularly interesting, therefore, that his closing involves asking about the structure of the meeting: who had formed the committee, and who was chairman, secretary, and the membership. The meeting had been called, as all

traditional meetings are, by a gwaunga' $i$ 'elder,' and when people arrived, they were expected to engage in discussion and speech-making. Meshach mistakenly anticipated a more bureaucratic, modernized structure, and he was hopeful of being elected chairman. This is the way that such things are always handled today in SSEC villages.

Miriama's speech was highly praised after the feast, but Meshach's was met with an embarrassed silence. An Anglican man of Meshach's approximate age broke the silence, turning the focus of the meeting back to the court case (so Meshach never got an answer to his question about the "committee").

Meshach's speech was not talked about later when elders gathered in smaller groups to discuss what of importance had been said at the meeting. His speech and its reception illustrated the differential social consequences of language style choice in West Kwara'ae.

\section{DISCUSSION}

Earlier we pointed to several weaknesses in accommodation theory and Bell's audience design framework, four of which we return to here.

1) Choice of discourse style and non-verbal patterns is at least as important as choice of linguistic code in claiming identity with a social group: Accommodation theory and audience design privilege linguistic code over discourse style, paralinguistics, gesture, kinesics, and other non-verbal characteristics of communication. Our study has shown the importance of examining all these factors and their 
interrelationships. Selecting appropriate linguistic features is only part of what it takes to enact being Anglican or

Evangelical, and examining linguistic code alone is

insufficient for unambiguously defining a behavioral

performance as Evangelical or Anglican. Moreover, the non-

linguistic factors we have identified carry highly significant symbolic messages about values and personal goals that clarify the meaning of code choice itself.

2) It cannot be assumed that speakers command a range of competencies and can freely choose among them: Both accommodation theory and audience design do make this assumption, yet in the speakers we examined, competence and choice were definitely interrelated, and positive or negative social outcomes were distributed accordingly. This point was particularly clear in Meschach's case, where his poor skills in high-rhetoric Kwara'ae together with his misconstrued framing of the event (as a Western-style rather than traditional meeting) undercut the message he intended to communicate, as well as his social standing within the traditional system.

3) Significant individual variation is apparent in whether one's audience design decisions remain relatively stable and reenacted across changing contexts, or reflect genuine choices within a repertoire as shaped by immediate contextual influences: As groups, Evangelicals appear to maintain their reference-group orientation across changing contexts, in comparison with Anglican tendencies to respond to immediate contextual influences. However, we have noticed considerable individual variation especially among older Evangelicals in the degree to which immediate context influences choice. Another pattern is illustrated by philemon and others like him who have changed church affiliation once or twice. In these cases, a long period with a relatively stable audience design reenacted across contexts alternates with another long period of making choices within a repertoire in response to immediate context.

4) Speakers may be ambivalent about the social value of the linguistic codes they know, about the extent of their own competence in them, and about the relative merit of choosing a particular code in complex social circumstances: Ambivalence is not taken seriously by either accommodation theory or audience design frameworks, yet it plays an important role not only in people's immediate interactional choices, but in longterm decisions of social groups. We see this in Kwara'ae, where linguistic and social conditions are continuing to change. 
Although in this paper we have drawn a sharp distinction between SSEC and CM discourse and behavioral styles, language use and self-presentation is changing rapidly in West Kwara'ae. Especially since the charismatic movement among Anglicans and Catholics in the early 1980s, which was brought to the Pacific islands by clergy from England and other Commonwealth countries, distinctions between SSEC and CM have begun to blur. These changes have taken two directions.

One, as might be expected, is that a younger generation identifies more and more with contemporary social change and economic development. English and Pijin are increasingly influential in village life because they are identified with education which islanders are eager to acquire, viewing education as the way out of their increasing poverty. In the large, influential Anglican villages of $\mathrm{Bi}$ 'O and Buma -- noted for their preservation of traditional art, music, and dance -the Evangelical style of mixing Pijin and English words and phrases into talk is increasingly popular. People seem to be attempting to close the growing gap they perceive between themselves and those who have been off island and are rising economically.

At the same time, some Evangelicals have joined Anglicans in collecting and recording genealogical and other forms of traditional knowledge. On one hand, these efforts are a response to the fact that "ownership" of traditional knowledge has value in arguing land claims in local courts, where written decisions set a powerful precedent against future hostile claims. On the other hand, Evangelical efforts to record other kinds of traditional knowledge reveal the degree to which that knowledge has already been lost or been rendered harmless, no longer threatening their current beliefs. In fact, people's attitudes towards traditional knowledge is as ambivalent as their attitudes towards the linguistic codes in their community.

Because Pijin and English are modeled and thus promoted by opinion leaders in rural areas of Malaita, we expect that Evangelical linguistic and interactional innovations will continue to make gains in Kwara'ae district, and eventually replace the more conservative language and style of Anglicans (and those few who follow the traditional ancestral religion). We think that the key to whether or when Pijin replaces Kwara'ae in rural households lies with Kwara'ae women, who have so far been more linguistically conservative than men, and whose linguistic behavior is very important in child socialization. 
NOTES

Acknowledgements: We are especially indebted to susan U. Philips, Lamont Lindstrom, and Donald Brenneis for raising important theoretical issues with regard to Giles' and Bell's models in reading an earlier version of this paper (presented at the Association for Social Anthropology in oceania meeting, March 1990, Kaua'i). Thanks also to Bambi Shieffelin and William Thurston for their suggestions for revision.

1. Tryon and Hackman (1983) cite 70 languages/dialects in the Solomons, earlier sources as many as 90. See Hudson (1980) for a critical review of problems in determining the criteria for "language" vs. "dialect".

2. Giles et al. (1977) do not discuss response from the subordinate group when the possibility of social change is perceived unfavorably by the dominant group. Fasold's (1984) table therefore has an empty cell here, although he believes that the least progressive members of the subordinate group would converge ( $p$. 191). We have entered "variable" into this cell to indicate that under such conditions, subordinate group members may exhibit patterns of convergence, nonconvergence, or divergence. For instance, they may diverge, seeking to strengthen the social and linguistic differences between groups to increase in-group identity.

3. Among those not to be discussed further here, the Roman Catholic mission (established 1898) used local vernaculars and Pijin until after World War II; the Methodist mission (1902) in the Western Solomons used local languages and English; and the Seventh Day Adventist mission (1914) used mainly English (primarily to attract converts; see Tryon 1979).

4. The SSEC/CM competition is representative of competition on Malaita between $\mathrm{CM}$ and the Roman Catholic Church (neither of which proselytize) on one hand, and the SSEC, Seventh Day Adventists, and Jehovah's Witnesses (who use primarily Pijin and English) on the other. Along the Malaita Road in West Kwara'ae, a villager receives visits from Jehovah's Witnesses as often as a suburban American receives them. With regard to terms used to refer to the churches, the Kwara'ae call SSEC sikoso/sikos (SI Pijin), reflecting its first establishment (people coming down from the mountains to attend a service said that they were going to the sikos). The CM is still locally called melanesian mison (pronouncing each vowel of "melanesian" separately, and not palatalizing the "s"), or simply 
misono/mison. Other church labels include katliki/katlik (Roman Catholic), dioha (Jehovah's Witness), and SDA (Seventh Day Adventist). Contrasted with Christian labels is tolo (following ancestral religion; literally, mountainous interior).

5. In Kwara'ae, a missionary or catechist sent to a nonChristianized village is said to 'ifingia, 'open it,' i.e., opening closed minds to christianity. An alternative term is 'oia, 'break it,' meaning to sever ties to tradition. The latter term refers to both religious and political ties, and thus means to become subjected to the hegemony of the colonial (now national) government. During missionization, the Anglicans sent members of the Melanesian Brotherhood (at first called Tasiu [Mota]) to "open" Kwara'ae villages. The Brothers were Solomon Islanders (trained at the Melansian Brotherhood center near Fauābu) who wore a special uniform. Once a village was "opened," a permanent catechist (trained at Norfolk Island or the Melanesian Mission headquarters at Fiu in West Kwara'ae) would take over, and the Brother who had "opened" the village would move on to another. This system allowed the MM to expand rapidly. At first the SSEM used individual missionaries with weak follow-up when a missionary left. Later they imitated the Anglican system by creating lifurongo (Iit., spread the message, in this case the Gospel) groups which functioned similarly to the Melanesian Brotherhood.

6. An example of kin obligations is the brideprice (bridewealth) system. Anglicans continue the traditional brideprice of shell mani (money or valuables) and an exchange of pigs, which Evangelicals have forbidden as "sinful" and "pagan." Yet what has actually occurred is a reorganization of the brideprice system. On one hand, the CM condones traditional practices but has severely limited the size of the brideprice. Demanding more results in temporary excommunication. On the other hand, the SSEC forbids -- with the threat of excommunication -- paying or receiving shell money and exchanging pigs. But the bride's parents can demand a lavish pati (party) and gifts. As there are no church-set limits on either, the cost of an SSEC marriage can far exceed that of an Anglican marriage. Thus, both churches allow a brideprice (whatever it may be called), but: 1) the CM regulates its size and the SSEC does not; and 2) the SSEC considers the CM's practices to be "pagan" and the CM considers the SSEC's practices to be discriminatory (against Anglicans) and very expensive.

7. The most popular musics in the solomons currently are 
Gospel rock and Reggae. Gospel rock by local bands is played daily on Solomons Radio and is readily available for purchase on cassettte audiotapes. Maranatha, one of the most popular and polished local groups, is apparently affiliated with the world-wide fundamentalist christian youth group Maranatha, which has been said to have "cultic" characteristics (Gazdik 1989).

8. We have not conducted a systematic survey of language attitudes in Kwara'ae. Rather we are basing our discussion on several years of fieldwork in which detailed notes were taken on statements about language behavior made in our presence or reported to us. We have also tape recorded several hundred hours of discourse data in Kwara'ae in a wide range of private and public contexts. In 1979, we formed the Kwara'ae Language and culture committee, with members from SSEC and CM communities, to assist us with preparing a Kwara'ae dictionary and grammar. Committee meetings elicited lengthy discussions of language attitudes in West Kwara'ae (all tape recorded). Finally, we base some of our interpretations on Gegeo's knowledge as a cultural insider. We are confident that a systematic survey would support our description.

9. Plantation workers returning from Fiji may have brought Fijian liturgical terms, or Fijian words may have been borrowed into Mota at Norfolk Island. For instance, in the $1930 \mathrm{~s} \mathrm{Jack}$ Gwaufungu returned to the Fiu area of West Kwara'ae from Fiji, where he had worked on a plantation and then served as police constable for several years. Although the $C M$ was already at Fiu, Gwaufungu's active role as missionary following his return led to his being referred to, even today, as the person who "brought the church to Fiu" (even though people are aware of the true chronology of events). Transcription conventions for Table 4 and other Kwara'ae examples in this paper: boldface = word with English root or derivation, or Solomons Islands Pijin. Other transcription conventions for this paper: : = elongated or held vowel (number of colons following the vowel indicates approximate length of hold in half seconds) $;+=$ bound morpheme; caus = causative prefix; $C L=$ classifier; gen = genitive; nom = nominative suffix; poss = possessive pronoun suffix; $\mathrm{sg}=$ singular (pronoun); $\mathrm{SM}=$ subject marker.

10. For example, Deck translated the biblical sentence "if they persecute you in one city, flee unto another" as follows, attempting to express the meaning in everyday Kwara'ae discourse: 


$\begin{array}{llll}\text { kike ma'udukamu } & \text { ana } & \text { ta taone } \\ \text { they+SM destroy out of hate+you of }+3 s g, p o s s \text { some (Engl.) } & \\ \text { muke tafi } & \text { la'u tuana } & \text { ta taone } \\ \text { you+SM run away again toward+3sg,poss some (Engl.) }\end{array}$

Kike (Rade) is highly informal contraction for kira ka and muke for kaumulu ka; muke is redundant; la'u 'again' combined with another ta taone does not clearly express the idea of going to another city. The Anglican translation is:

$\begin{array}{llll}\text { difia kira ka ma'udukamu } & \text { ana } & \text { ta } \\ \text { if } & \text { they SM destroy out of hatred+you of }+3 s g, \text { poss some } \\ \text { fanoa tafi tuana } & \text { ta fanoa matamata } \\ \text { village run away toward+3sg,poss some village different }\end{array}$

11. Kwara'ae words in the text of this paper are in underlying form. Most words undergo a process of metathesis or anticipatory vowel copying in speech. Thus, transcript excerpts are represented as actually spoken.

12. A speech which builds to a conceptual and emotional climax, and then -- like Meshach's -- ends abruptly rather than winding down, is called ngururu, cut-off thing, in Kwara'ae. Meshach's speech would be described in Kwara'ae as a "poorly woven basket." 
REFERENCES

Bell, A. (1984) Language style as audience design. Language in Society 13: 145-204.

Bennett, J.A. (1979) Solomon Islands Pidgin. In S.A. Wurm (ed.), New Guinea and the neighboring areas: a sociolinguistic laboratory. The Hague: Mouton.

Boutilier, J.A., D.T. Hughes, and S.W. Tiffany (eds.) (1978) Mission, church and sect in Oceania. ASAO Monograph No. 6. Lanham, New York: University Press of Hawail.

Burke, K. (1969) A rhetoric of motives. Berkeley: University of California.

Erickson, F.D. (1975) Gatekeeping and the melting pot: interactions in counseling encounters. Harvard Educational Review $45(1)$ : 44-70.

Fasold, R. (1984) The sociolinguistics of society. Oxford: Basil Blackwell.

Gazdik, T. (1989) Some colleges warn students that cult-like methods are being used by Christian fundamentalist groups. Chronicle of Higher Education 36 (11) (15 November): A1, A42.

Giles, H. (1973) Accent mobility: a model and some data. Anthropological Linguistics 15: 87-105.

Giles, H., R. Bourhis, and D. Taylor (1977) Towards a theory of language in ethnic group relations. In H. Giles (ed.), Language, ethnicity and intergroup relations. London: Academic Press.

Hilliard, D. (1966) Protestant missions in the Solomon Islands. Unpublished Ph.D. thesis, Australian National University.

Hilliard, D. (1978) God's gentlemen: a history of the Melanesian Mission 1849-1942. St. Lucia: University of Queensland Press.

Hudson, R.A. (1980) Sociolinguistics. Cambridge: Cambridge University Press. 
Jourdan, C. (1986) Sapos yumi mitim yumi: urbanization and creolization in the Solomon Islands. Unpublished Ph.D. thesis. Australian National University.

Jourdan, C. (1989) Nativization and Anglicization in Solomon Islands Pijin. World Englishes 8,1: 25-36.

McGavin, P.A., and K. Gannicott (1989) Central or local? management policy for schooling in the Solomon Islands. Economics and Management Working Paper No. 1/1989, April. Campbell, ACT: Department of Economics and Management, University College, University of New South Wales, Australian Defence Force.

Searle, I. (1970) Education in the BSIP: History and structure. Mimeographed White Paper. Honiara: British Solomons Training college.

Siegel, J. (1986) Plantation Pidgin Fijian. Oceanic Linguistics 21: 1-72.

Tryon, D.T. (1979) Remarks on the language situation in the Solomon Islands. In S.A. Wurm (ed.), New Guinea and the neighbouring areas: A sociolinguistic laboratory. The Hague: Mouton.

Tryon, D.T., and B.D. Hackman (1983) Solomon Islands languages: an internal classification. Pacific Linguistics Series, C-72. Canberra: Australian National University.

Watson-Gegeo, K.A. (1987) English in the Solomon Islands. World Englishes 6(1): 21-32.

Watson-Gegeo, K.A., and D.W. Gegeo (1988) Schooling, knowledge and power: Social transformation in the Solomon Islands. University of Hawai'i Working papers in ESL 7(1): $119-140$.

Watson-Gegeo, K.A., and D.W. Gegeo (1990) shaping the mind and straightening out conflicts: The discourse of Kwara'ae family counseling. In Watson-Gegeo and G.M. White (eds.), Disentangling: Conflict discourse in Pacific Societies. In press, Stanford University Press.

White, G.M., D. Akin, D.W. Gegeo, and K.A. Watson-Gegeo (1988) The big death: Solomon Islanders remember World war II. Suva: University of South Pacific Press. 
White, G.M., and L. Lindstrom (eds.) (1989) The Pacific Theater: island representations of World War II. Honolulu: University of Hawai'i Press.

Whiteman, D. (1983) Melanesians and missionaries: an ethnohistorical study of social and religious change in the southwest Pacific. Pasadena, CA: William Carey. 